\title{
Fire and Smoke Phenomenon in West Najaf City -Southwest Iraq
}

\author{
Abdulkadhim J. Alabidi', Saadi A. M. Al-Dahaan1, Nadhir Al-Ansari² \\ ${ }^{1}$ Department of Geology, Faculty of Science, University of Kufa, Kufa, Iraq \\ ${ }^{2}$ Lulea University of Technology, Lulea, Sweden \\ Email: 1abdulkhadhimj.alabidy@uokufa.edu.iq, saadi.aldahan@uokufa.edu.iq,nadhir.alansari@ltu.se
}

How to cite this paper: Alabidi, A.J., AlDahaan, S.A.M. and Al-Ansari, N. (2019) Fire and Smoke Phenomenon in West Najaf City -Southwest Iraq. Engineering, 11, 791-800. https://doi.org/10.4236/eng.2019.1112053

Received: November 9, 2019

Accepted: November 23, 2019

Published: November 26, 2019

Copyright (c) 2019 by author(s) and Scientific Research Publishing Inc. This work is licensed under the Creative Commons Attribution International License (CC BY 4.0).

http://creativecommons.org/licenses/by/4.0/

\begin{abstract}
A strange phenomenon of fire taking place at Arruhban area west $\mathrm{Bahr}-\mathrm{Al}$ Najaf area in Iraq was noticed in 2010 and smoke continued many months; this phenomenon reappeared many years later. This site is part of Bahr-Al Najaf-Iraq NE Arabian plate, located in flat area near an archeological site of Christian temple called Tel Arruhban. To understand the causes for this fire in a non-residential area, field observations from repeated visits between 2010 and 2018 and on-site excavation operations were conducted. The results of analysis of soil samples, and on-site detection for gases and vapors showed that the phenomenon of burning and smoke generated at this site was due to external influences and that the presence of soil rich with organic materials helped to the existence of this phenomenon.
\end{abstract}

\section{Keywords}

Smoke Phenomenon, Bahr-Al Najaf, Tel Arruhban, Detected Gases

\section{Introduction}

The study site (Arruhban area) is located at $4400038 \mathrm{E}$ and $3200239 \mathrm{~N}$, about $25 \mathrm{~km}$ west of Al Najaf City, near an archeological site of Christian temple called Tel Arruhban (Figure 1). This site is located in a desert flat area next to a palms grove (like garden). It contains some desert plants, passed by a very shallow waterway (Figure 1). There was an artesian well feeding the area with water through a water channel. This site, as mentioned by some local residents, was part of a swamp where colonies of plant grew and then buried with sediments and soil later. In 2010, a fire was seen in the area, and smoke continued in the site until the rainy season then smoke ceased. After many years this phenomenon was reappeared and smoke continued for many weeks. 


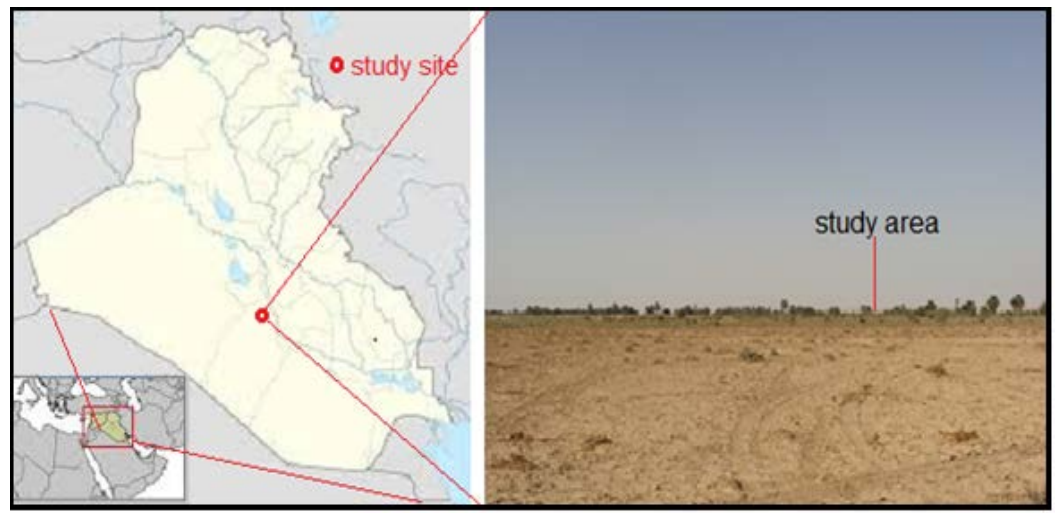

Figure 1. Location map of Iraq and the location of the study area.

The phenomenon of smoke and fire is well known globally and there are many sites in the world that have known this phenomenon. The smoke Hills in Canada [1], Eternal Flame Falls, Orchard Park, New York [2], Mont Chimaera in Turkey [3], Baba Gurgur in Iraq [4], Burning Mountain in Australia [5], Erta Ale in Ethiopia [6], Door to the hell in Turkmenistan [7], Water and fire Cave [8], Burning mountain in Germany [9], Mrapen in Indonesia [10], Jawalamukhi in India [11], Chestnut Ridge Park in Pennsylvania [12] and Yanar Dag in Azerbaijan [6] are some of these sites. In most of these sites, the fire is related to leakage of gases while some of them related to burning in some types of rocky layers or it might be due to volcanic activities.

\section{Geology of the Area}

The study site is a part of Bahr-Al Najaf which is located in the northeast of Iraqi Southern desert. The origin of Bahr-Al Najaf is attributed to Sag Ponds, whereas the sediments belong to marine origin [13]. According to the geological map quaternary deposits are exposed in this site (Figure 2).

Tectonically this site is located approximately within Anah-Abu Jir fault system zone which represent the border between Inner Arabian Platform and Outer Arabian Platform (Figure 3).

\section{Field Observations}

Several visits were conducted to the area and field observations, and photographs were recorded since that phenomenon occurred in October 2010. It was found that the area of the initial burned site does not exceed $5 \mathrm{~m} \times 12 \mathrm{~m}$ (Figure 4).

Dry weeds were burned in several places in the area surrounding this site. There was a palm grove surrounded by a water channel. The channel takes water from an artesian well near the burned site. After few days, the fire diminished within the site and the area started to cool. The ground level in the site collapsed. Slightly elevated areas surrounding the burned site continued smoking and gradually collapsed (Figure 5). Continued observations confirmed that the burned locality did not show smoke or fire again. 
There are different views about the origin of this phenomenon. There is a negative repercussion on the population of the region. The researchers believe however, that this phenomenon is surficial and not dangerous. The site was excavated with an excavator as shown in Figure 6(a). It was found that the depth of burnt soil did not exceed $2 \mathrm{~m}$, and there was clayey soil with no effect of burning below it (Figure 6(b)).

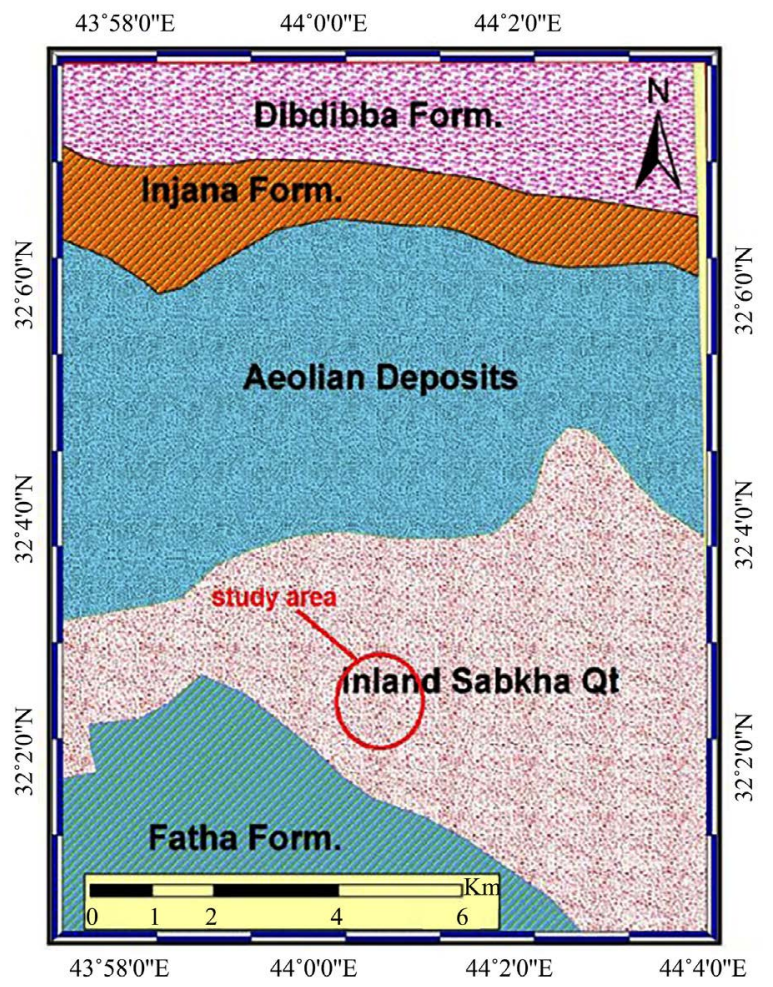

Figure 2. Geological map of the study area (modified after [14]).

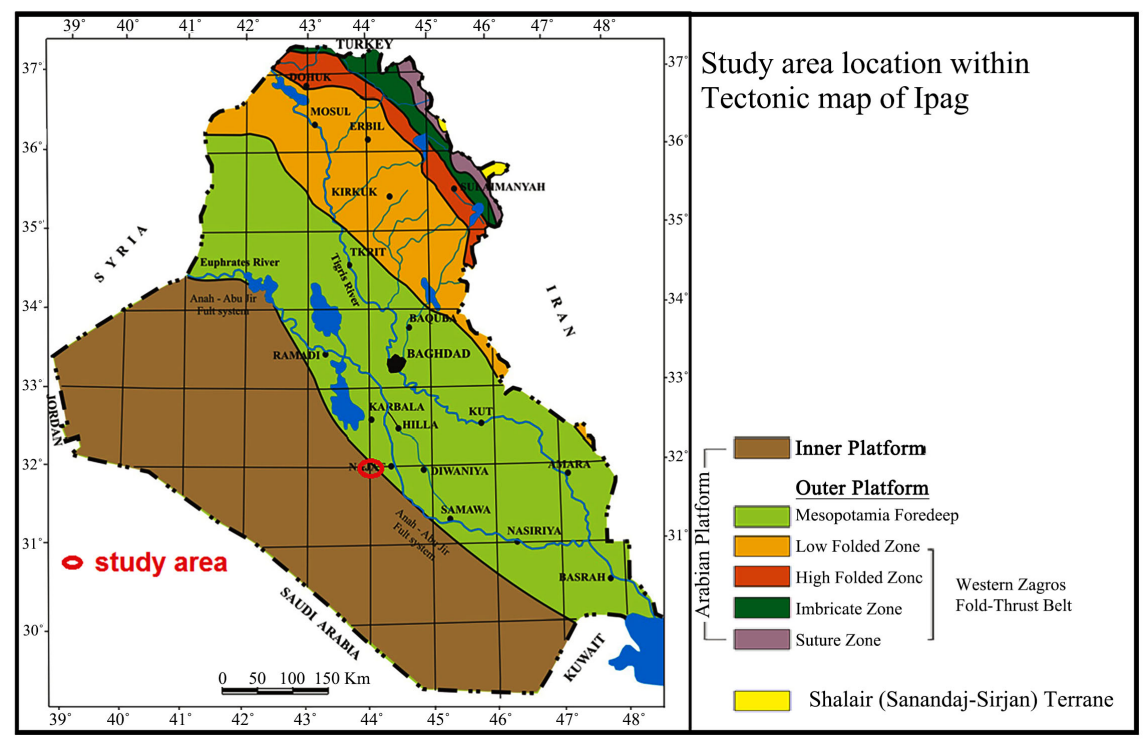

Figure 3. Study area location within Tectonic map of Iraq (after [15]). 


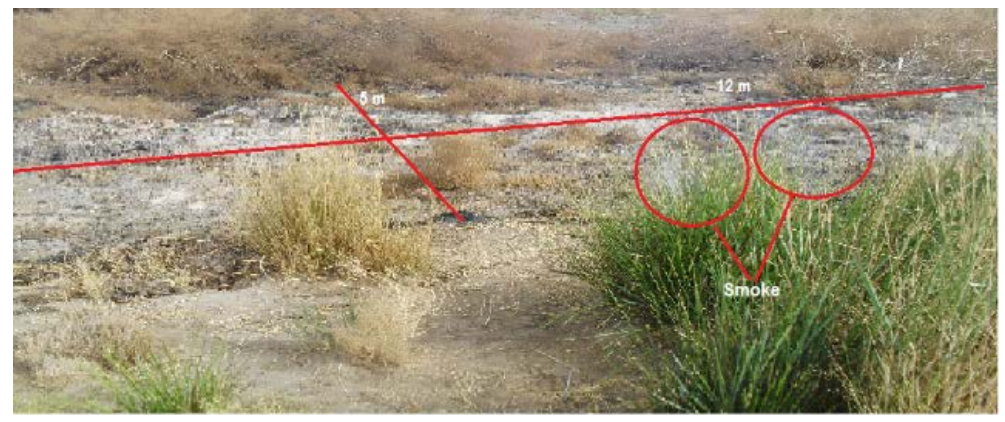

Figure 4. The location of the first burning area in the site in 2010 (red color shows the areas of emitted smoke).

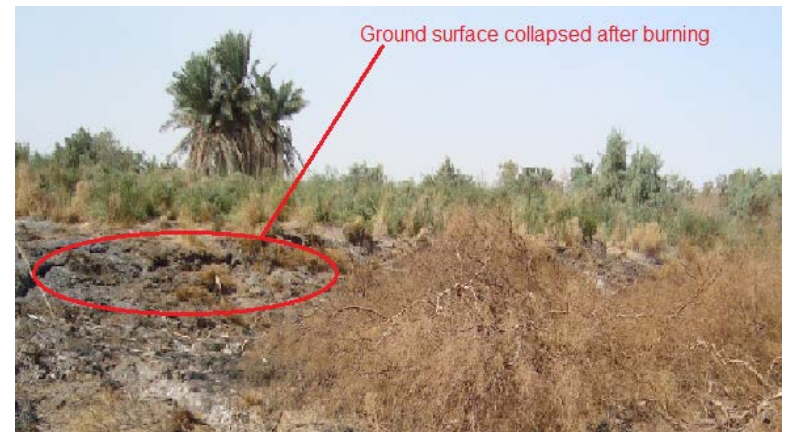

Figure 5. The elevated areas surrounding the burning site continued smoking and gradually collapsed.

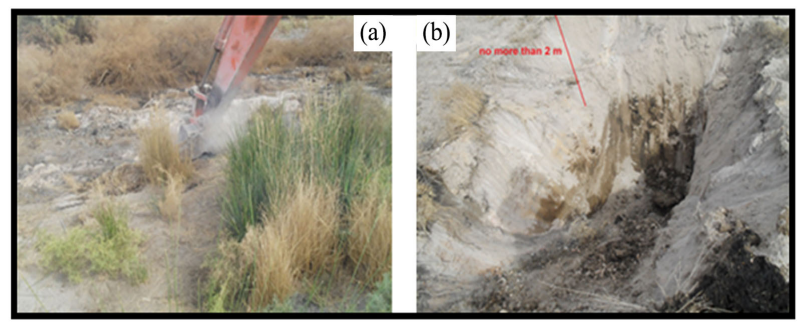

Figure 6. Shows excavation in the first site of the burning phenomenon (a), and the depth of burned material did not exceed $2 \mathrm{~m}$ (b).

It was also found that through the excavation that the slightly elevated areas surrounding the burned site consist of soil rich with organic matter (Figure 7). The phenomenon of smoke continued several months until rainy season began then it ceased.

The phenomenon of smoke was reappeared again in 2017. Several visits were conducted to the site at the end of 2017 and during February and March 2018. It was found that the phenomenon of incineration expanded and exceeded the above-mentioned water channel. This channel was dry because the artesian well supplying water to the channel dried three years ago (may be due to unfair and uncultivated drilling of artesian wells in the region) (Figure 8).

It was evident that little smoke was rising in the slightly higher locations which consist of soil rich in organic matter (Figure 9). After the completion of burning of the organic matter in the soil of these locations, subsidence started. Then, the 
area started to be cold, and did not show any smoke or burning phenomenon again. In some locations, the burned soil changed its color and it became either reddish or white gray (Figure 10). Some white or yellow materials were also observed near some of fissures or openings where the smoke was emitted from (Figure 11).

In a visit to the site accompanied by the Civil Defense team, a phD6 and FTX devices were used (Figure 12). The first was used to measure flammable, dangerous and other gases and vapors. The second device was used to analyze solid materials and determine their chemical composition.

The results of the measurements taken are shown in Table 1. In this table, the chemical composition of the soil and the gases detected in five stations on site are tabulated. It was noticed that there was no flammable gases detected on the site during the measurements.

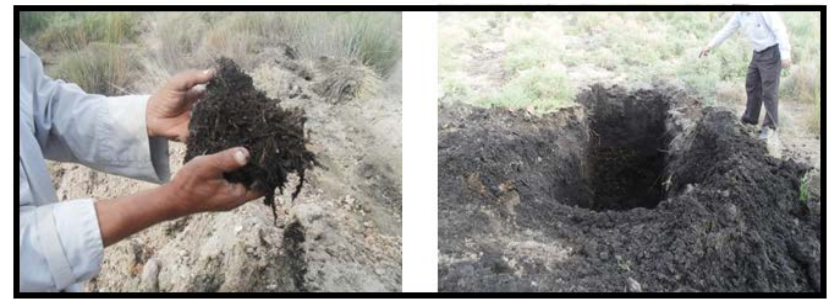

Figure 7. Shows that the soil surrounding the burned site was rich with organic matter.

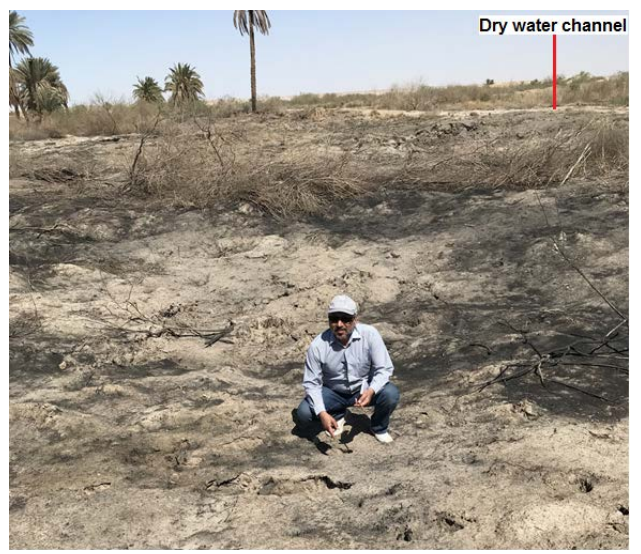

Figure 8. Shows the burning area and its expansion after the dryness of the water channel.

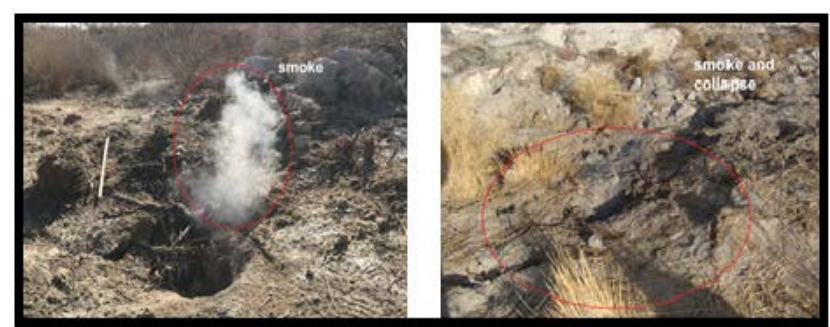

Figure 9. Smoke rose in the slightly higher locations which consist of soil rich in organic matter. 


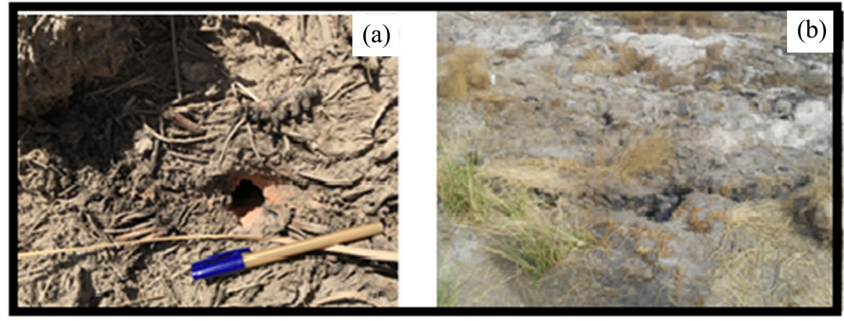

Figure 10. The color of burnt soil red (a), white gray (b).

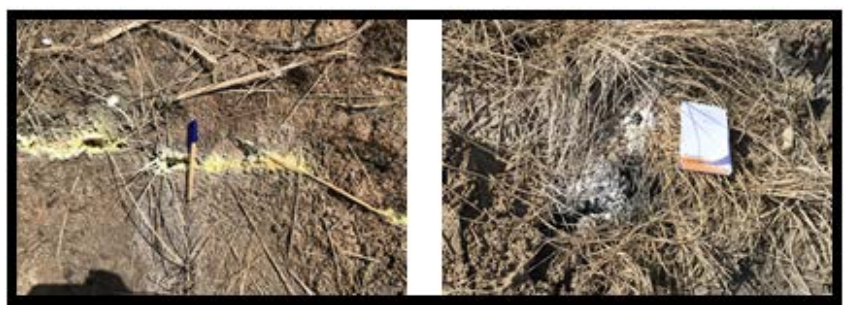

Figure 11. White or yellow materials observed near some of fissures or openings from which the smoke were emitted.

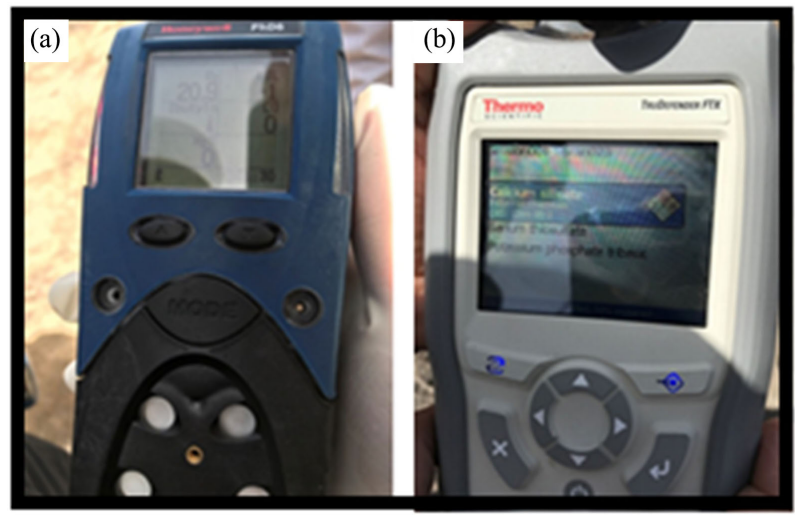

Figure 12. Instruments used in the field. (a) phD6 device and (b) FTX device.

Table 1. Chemical composition of soil materials and gases detected in stations of study site.

\begin{tabular}{|c|c|c|c|c|c|c|}
\hline \multirow{2}{*}{$\begin{array}{l}\text { Station } \\
\text { number }\end{array}$} & \multirow{2}{*}{ Coordinates } & \multirow{2}{*}{$\begin{array}{l}\text { Chemical composition of } \\
\text { soil materials using FTX device }\end{array}$} & \multicolumn{4}{|c|}{ Gases detected using phD6 device } \\
\hline & & & $\mathrm{O}_{2}$ & $\mathrm{CO}$ & $\mathrm{H}_{2} \mathrm{~S}$ & Explosive gases \\
\hline 1 & $\begin{array}{l}440038 \mathrm{E} \\
320240 \mathrm{~N}\end{array}$ & $\begin{array}{c}\text { Calcium Silicate }(42 \%) \\
\text { Barium Thiosulfate (12\%) } \\
\text { Potassium Phosphate (4\%) }\end{array}$ & 19.9 & 210 & 2 & None \\
\hline 2 & $\begin{array}{l}440041 \mathrm{E} \\
320232 \mathrm{~N}\end{array}$ & Calcium Silicate $(70 \%)$ & 20.7 & 129 & 0 & None \\
\hline 3 & $\begin{array}{l}440049 \mathrm{E} \\
320233 \mathrm{~N}\end{array}$ & $\begin{array}{c}\text { Calcium Sulfate (60\%) } \\
\text { Iron III Sulfate Hydrate (5\%) } \\
\text { Tin II Phosphate Hydrate (1\%) }\end{array}$ & 20.2 & 118 & 2 & None \\
\hline 4 & $\begin{array}{l}440041 \mathrm{E} \\
320239 \mathrm{~N}\end{array}$ & $\begin{array}{c}\text { Methylene diamine-Dihydrochloride (69\%) } \\
\text { Potassium Acetate (4\%) }\end{array}$ & 21 & 1 & 0 & None \\
\hline 5 & $\begin{array}{l}440041 \mathrm{E} \\
320237 \mathrm{~N}\end{array}$ & $\begin{array}{c}\text { Ammonium Sulfate (48\%) } \\
\text { Ammonium Bromide (20\%) }\end{array}$ & 21 & 1 & 1 & None \\
\hline
\end{tabular}


The results in Table 1 indicate:

- Calcium Silicate may result from high temperature burning of organic sandy soils [16].

- Calcium Sulfate may result from gypsum dehydrating due to heating [17].

- Ammonium sulfate may occur naturally due to coal fires [18].

Field site study revealed that all the above mentioned materials and others cab be noticed in this site due to burning.

\section{Discussion and Interpretation}

Some geologists, during seminars and scientific meetings attribute smoking in this site to the flammable gases, and relate this phenomenon to the natural gas vents through deep fault (Abu Jir) in the area.

Field observations, excavation process and the results of the analysis of samples indicated that what happened at this site was due to external burning (external effect), and may have helped to ignite within the presence of some combustible gases resulting from the decomposition of organic matter in the soil.

The proposed scenario for this phenomenon is summarized as follows:

- There are trees on the site characterized by a long burning time (called Tarfa) as well as there are soils rich in organic materials resulting from the growth of plant colonies dense roots with continuous burial of sediments. These two kinds helped to continue the combustion and smoking in the site.

- The combustion of these trees and arrival of fire to their roots have led to the gradual burning of the organic materials in the above-mentioned soils. The presence of dense network of holes of burrowing animals in these organic soils has provided sufficient air (oxygen) for combustion of organic matter in the soil.

- The smell in the region attributed to non-dry organic materials and the roots of plants which gradually dry, burned and smokes.

- The burning of organic matter in the soil leads to the loss of large part of the content of the soil which leads to collapse.

The following points support this opinion:

1) If the combustion was caused by gases emitted from deep depth, the fire must continue at same position of first combustion or at least show re-burning at the same position, this did not happen, but there was an expansion of the phenomenon of combustion and smoke to include new areas surrounding the point of the initial combustion.

2) The phenomenon of burning and smoke continued to be obtained only in the relatively high areas surrounding the initial incineration sites (position), which consist of organic soil and then these relatively high areas collapse (subside) after the burning process leading to the expansion of the primary combustion zone and does not burned or smoke again.

3) If this phenomenon resulted from leakage of gases due to movement of deep faults, the surface reflections (implications) of this movement must be long or continuous as linear features along that deep fault. So the lake of linear con- 
tinuity of such a phenomenon or similar phenomena in the region refutes this possibility.

4) The study of satellite images (Figure 13) shows the variation in the wet area of the study site between 1984 and 2008, which supports the idea that the site was a swamp buried later with the soil rich in organic materials. The gradual combustion of organic matter in this soil helped prolong the phenomenon of smoke and expansion of burning in the site.

5) There were no detected gases in site except gases from burning soil and organic material.

6) The types of soil and sediments present in site can produce all the outputs shown in Table 1 when burned.

7) If the heat or gases were emitted from the depth, all plants and trees in the site must be dying. But it was found that burned palm and grass on the site began to grow again (Figure 14).

\section{Conclusion}

A strange phenomenon of fire taking place at Arruhban area west Bahr-Al Najaf area in Iraq was noticed in 2010 and smoke continued many months; this phenomenon reappeared many years later. To find out the causes of this phenomenon, extensive field and lab work was conducted. According to the results, it is evident that this was due to external burning (external effect), and may have helped to ignite within the presence of some combustible gases resulting from
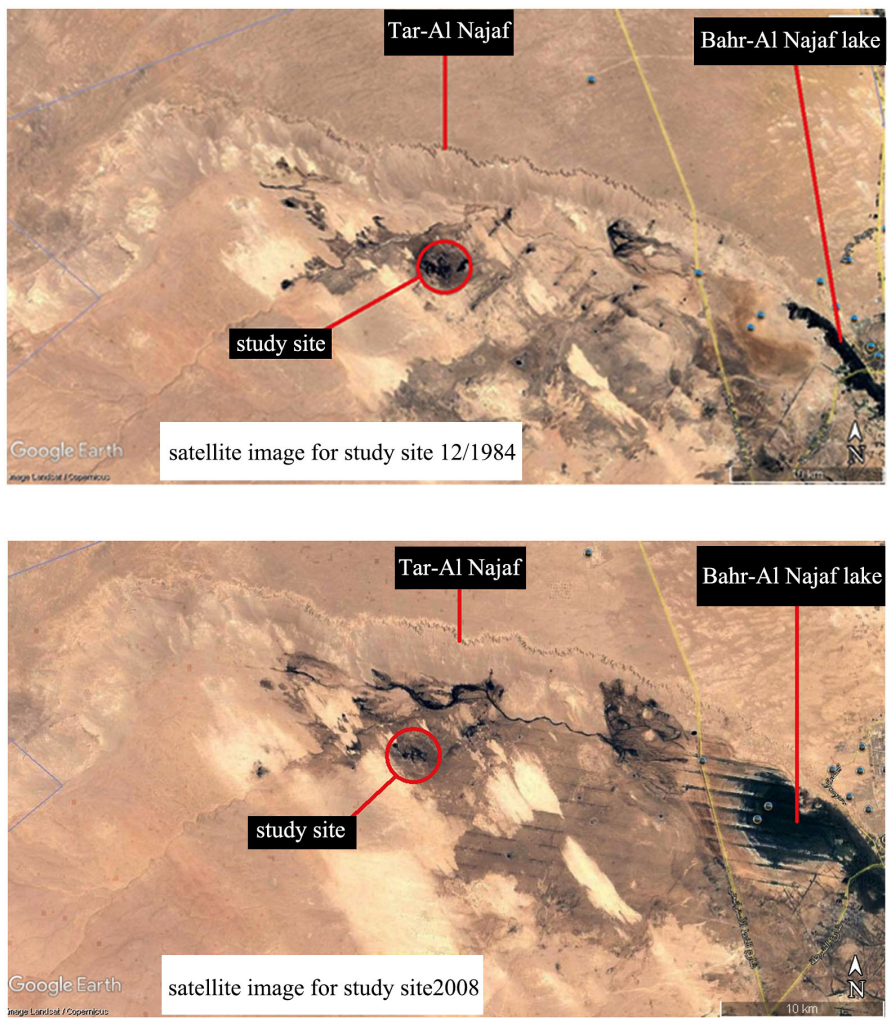

Figure 13. Satellite images of the study site at 1984 and 2008. 


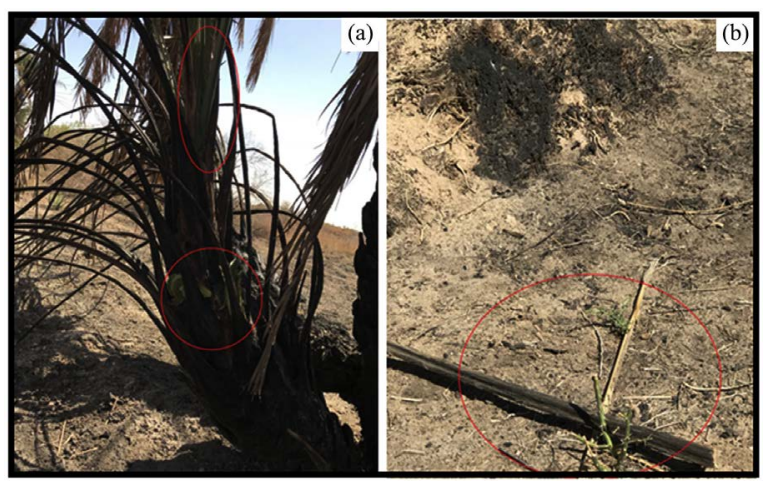

Figure 14. Burned palm trees (a), and weeds (b) on the site are starting to grow again.

the decomposition of organic matter in the soil. The area is characterized by long burning time (called Tarfa) as well as there are soils rich in organic materials resulting from the growth of plant colonies dense roots with continuous burial of sediments. The combustion of these trees led to the gradual burning of the organic materials in soil. Sufficient air (oxygen) for combustion of organic matter in the soil is obtained through the dense network of holes of burrowing animals in these organic soils. The smell in the region attributed to non-dry organic materials and the roots of plants. Burning of organic matter in the soil leads to the loss of large part of its content which leads to its collapse.

\section{Conflicts of Interest}

The authors declare no conflicts of interest regarding the publication of this paper.

\section{References}

[1] Mathews, W.H. and Bustin, R.M. (1984) Why Do the Smoking Hills Smoke? Canadian Journal of Earth Sciences, 21, 737-742. https://doi.org/10.1139/e84-080

[2] Etiope, G., Drobniak, A. and Schimmelmannd, A. (2013) Natural Seepage of Shale Gas and the Origin of "Eternal Flames" in the Northern Appalachian Basin, USA. Marine and Petroleum Geology, 43, 178-186.

https://doi.org/10.1016/j.marpetgeo.2013.02.009

[3] Hosgörmez, H. (2007) Origin of the Natural Gas Seep of Çirali (Chimera), Turkey: Site of the First Olympic Fire. Journal of Asian Earth Sciences, 30, 131-141. https://doi.org/10.1016/j.jseaes.2006.08.002

[4] Baba Gurgur-Eternal Fire of Iraq, 2019, Worldatlas. https://www.worldatlas.com/articles/baba-gurgur-eternal-fire-of-iraq.html

[5] Burning Mountain Nature Reserve (2019) NSW National Parks and Wildlife Services.

https://www.nationalparks.nsw.gov.au/visit-a-park/parks/burning-mountain-nature -reserve/learn-more

[6] Leary, C. (2014) 9 Naturally Occurring Eternal Flames. Mother of Nature Network. https://www.mnn.com/earth-matters/wilderness-resources/blogs/9-naturally-occurr ing-eternal-flames 
[7] Gunther, S. (2012) Watch: The "Door to Hell" of Turkmenistan. https://www.mnn.com/earth-matters/energy/blogs/watch-the-door-to-hell-of-turk menistan

[8] Water and Fire Cave (2019) Round Taiwan Round. https://www.rtaiwanr.com/tainan/water-and-fire-cave

[9] Burning Mountain Nature Reserve (2019) Learn More about Why This Part Is Special, NSW Parks and Wildlife Service.

[10] Wikipedia https://en.wikipedia.org/wiki/Mrapen

[11] Jwalamukhi Temple (2019) Indian Mirror. http://www.indianmirror.com/temples/jwalamukhi-temple.html

[12] Hickman, M. (2013) 7 Modern-Day Ghost Towns, Mother of Nature Network. https://www.mnn.com/lifestyle/eco-tourism/photos/7-modern-day-ghost-towns/ce ntralia-pa

[13] Ma'ala, K.A. (2009) Geomorphology of Iraqi Southern Desert in Special Issue: Geology of the Southern Desert, State Company of Geological Survey and Mining.

[14] Sissakian, V.K. and Fouad, S.F. (2012) Geological Map of Iraq, Scale 1:1,000,000. 4th Edition. Geosurv, Baghdad.

[15] Fouad, S.F.A. (2015) Tectonic Map of Iraq, Scale 1: 1000 000. 3rd Edition. Iraqi Bulletin of Geology and Mining, 11, 1-7. https://doi.org/10.2118/92339-MS

[16] Bauer, S., Gronewald, P., Hamilton, J. and Mansure, A. (2005) High-Temperature Plug Formation with Silicates. Proceedings of Thirtieth Workshop on Geothermal Reservoir Engineering, Stanford University, Stanford, CA, 31 January-2 February 2005.

[17] Taylor, H.F.W. (1990) Cement Chemistry, Academic Press, New York, 33-34.

[18] Chang, R. (2006) Chemistry. 9th Edition, McGraw-Hill Science, New York. 